ARTICLE HISTORY: Received: October 20, 2021 Accepted: December 12, 2021 Published: December 19, 2021

\title{
HO CHI MINH'S SKILL AND SPIRIT IN 30 YEARS OF REVOLUTIONARY ACTIVITY ABROAD (1911 -
} 1941)

\author{
Tran Thi Minh Tuyet \\ PhD in History, Associate Professor, Senior Lecturer, \\ Faculty of Ho Chi Minh's thoughts \\ Academy of Journalism and Communication Hanoi \\ Socialist Republic of Vietnam
}

\begin{abstract}
The outstanding career of President Ho Chi Minh, a new chapter in the history of the Vietnamese nation, started with the event of the young Nguyen Tat Thanh (a name of President Ho Chi Minh) headed overseas to seek a path to national liberation on June 5, 1911. It is true to say that "It is the first step that counts." The 30 years of revolutionary activity abroad (1911 - 1941) was the most exciting period, but it was also the most arduous and challenging one in his revolutionary life. The author would like to discuss Ho Chi Minh's extraordinary skill and spirit in his journey, seeking a path, paving it, and guiding the Vietnamese to fight for independence and freedom.
\end{abstract}

Keywords: Ho Chi Minh, Vietnam, revolutionary activity, Vietnam history

Ho Chi Minh was known as a person, and if "without him, history could have followed a different way" [10, p. 152]. This truth was proved by the event Nguyen Tat Thanh, who later became President Ho Chi Minh, headed overseas to seek a way to save the country. He showed exceptional skill and spirit from the time he left the country (June 5, 1911) and during 30 years of revolutionary activity abroad. Ho Chi Minh's stuff in his journey seeking a path to national liberation is always the pride and endless inspiration of the Vietnamese's generations.

If discussing Ho Chi Minh's skill and spirit, it's obligatory to talk about the cultural and political bravery of a hero of national liberation and a great man of culture. His courage is reflected through his remarkable unique qualities: the sensitivity to the new, the outstanding vision, the creative thinking, the uncompromising determination, infinite fortitude, and the desire to conquer obstacles. During 30 years of strong revolutionary activity abroad, under different names, he traveled to many continents, lived in many countries, worked in many professions, completed many tasks, and overcame countless challenges and dangers to fulfill the noble mission, which was to find the way to save the country. Since leaving with nothing until returning with the position of a veteran leader and the head of the world's national liberation movement, Ho Chi Minh's singular skill and spirit are vividly demonstrated through the following aspects.

Firstly, Ho Chi Minh selected a completely different path because he was determined to find a new path to save the country.

Nguyen Tat Thanh was born and raised when the country was colonized. He witnessed the failures of many patriotic uprisings and movements against the French colony. Besides, the fact that not only Vietnam but also most of the Asia-African nations were colonized and failed in their fight for independence made him raise a series of questions: Why was the East considered the cultural cradle of Western civilization colonized by the West? Why did France raising the motto of "Liberty, Equality, and Fraternity" robbed freedom and trampled on the equal rights of other nations? Why was the Vietnamese feudal class defeating many northern invasions, powerless in the face of Western colonialism? Why couldn't the Vietnamese bourgeoisie lead the national liberation movement? It was impossible to answer those questions if only living in Vietnam, so he decided to "go abroad for a comprehensive understanding." However, his destination was not China like Ton That Thuyet and Nguyen Thuong Hien, nor Japan like Phan Boi Chau, but the West. First of all, it was France. He said: "I heard three French words: "Liberté, Egalité, Fraternité" (i.e., "Liberty, Equality, and Fraternity") for the first time when I was around 13 years old. From then on, I desired to get acquainted with French civilization as well as find out things behind those words" [3, p.461]. He also planned that "after considering how they turn them into truth, I will return to help our compatriots" [11, p.16]. He knows that if we want to win the French colonialists, we must understand France and the knowledge of the times. Besides, it is necessary to learn from the West with its outstanding scientific and technical strength. Therefore, on June 5, 1911, the young Nguyen Tat Thanh, using the name "Van Ba", boarded the vessel and went to French. This decision made him overcome not only the path of his predecessors but also the emerging concept of Greater East Asia at that time. His vision was shown not only in the direction but also in the purpose. The predecessors asked for help, but Nguyen Tat Thanh wanted to approach French civilization and learn Western society's operating mechanism and nature to find a way out of its enslavement. Being against the enemy by its culture is an extremely bold thought.

Nguyen Tat Thanh's skill and spirit were also reflected in how he found the way to save his homeland. A 21 -yearold boy from Nghe An Province with limited French, not much social knowledge, no relatives to accompany, and no sponsor crossed the ocean to the West. It was incredibly wise for him to choose to work as a sailor to go abroad and deepen his knowledge of the western world. With intuition and prudence of a genius, he acted under Vladimir Lenin's 
idea: "Only when we understand about the characteristics of an era, can we take into account the unique features of this country or that one" [12, p.174]. Reality has proved that contemporary thinking and awareness of the world situation help Ho Chi Minh find a path to national liberation in the same direction of history.

Secondly, Ho Chi Minh quickly recognized the nature of colonialism and capitalist society and engaged in political activities.

Nguyen Tat Thanh had taken advantage of all opportunities to visit new locations and learn about new cultures for ten years (1911-1920). He traveled around Africa and stopped at ports in Spain, Portugal, Tunisia, Congo, Dahomey, Senegal, Reunion and saw miseries of colonial nations with his own eyes. Therefore, he ignored the rhetoric that the colonists tried to "polish" the colonial regime and concluded: "Current colonialism is a thousand times as inhuman, terrible, and sinful as slavery. It destroyed the people in the colonies" [5, p.408]. When he witnessed many things with his own eyes, his feelings and thoughts also became great. Not only did he feel sorry for the pain of his nation, but also other ones. The aspiration for national liberation became the aspiration for the liberation of humankind. The policy of national unity became the policy of international solidarity. It could not be denied that Nguyen Ai Quoc (another name of President Ho Chi Minh) was the person who understood the colonial regime best and was also the one who condemned it and supported the colonial peoples in many communist leaders of the twentieth century.

He also lived and studied in France, the US, and the UK that were the most developed capitalist countries globally. The most important thing was that the poor young man, coming from a backward Eastern country, was not overwhelmed by Western capitalist society's flashiness, modernity, and wealth. When he arrived in France, he learned that there were impoverished people thanks to his keen observation and sympathy for the poor. A question emerged immediately: "Why doesn't the French "civilize" their countrymen before "civilizing" us?" [11, p.22]. He was not "culture-shocked", leading to the mentality of admiring and worshiping Western society. Instated of, he quickly realized its most significant limitation was oppression, including class oppression and national oppression. He also recognized the contrast between the lofty ideals of the bourgeois revolution and the injustice in life. After that, he concluded: "Despite the difference in skin color, there are only two types of people in the world, the exploiter and the exploited. The only true friendship is proletarian one (that means friendly cooperation between socialist countries)" [4, p.287]. When he asserted that imperialism and colonialism had brought the suffering for oppressed peoples and the national proletariat, the "halo" cover of capitalism had been stripped. Its flip side had been exposed. While many nations desired capitalism and even scholar Phan Chu Trinh intended to rely on France to overthrow the feudal system, Ho Chi Minh had realized the capitalist regime's flaws and core, revealing his extraordinary vision.

Coming to "metropolitan France," Nguyen Tat Thanh did not fall into the mentality of fear and national inferiority but took part in political activities quickly. He has a highly correct "thought" that supported and participated in organizations defending his homeland when choosing political organizations and doctrines. In 1919, he joined the Socialist Party because it was the only organization advocating and supporting the fight of the colonial peoples. Acting in the Phobia Club and being immersed in the life and struggle of the French working class allowed his political knowledge to be continuously enhanced. Thanks to that, his political prestige was steadily increasing. On June 18, 1919, on behalf of the Vietnamese patriots in France, he sent the Versailles Peace Conference an Eight-Point Claim to demand freedom and democracy for the Vietnamese. As a result, Nguyen Ai Quoc was the first Vietnamese to publicize the Indochina issue in front of global opinion. The "ignorance" of the bourgeois rulers led him to conclude: "The Wilson's theorem is just a big hoax" [4, p. 441]. The nations which would like to be liberated had to rely on their strength. Therefore, he became "the hope" of patriotic Vietnamese and "the obsession" of the colonial government.

Thirdly, Ho Chi Minh found the way to national liberation and became the co-founder of the French Communist Party $(P C F)$.

While many countries in Asia and Africa were engulfing in the darkness of colonialism, many patriots went out to discover a way to free their countries. However, it was too challenging for them to find the right path in a large world with many theories, political organizations, and growth trends. Whenever Nguyen Ai Quoc had to select a path, he utilized a supernatural "compass" that revealed that the Truth had to be a thing that benefited the people. The path that liberated and benefited the majority of the people was the right one. He remarked after studying the bourgeois revolutions: "The French Revolution is like the American Revolution, which is the capitalist revolution. It fails to achieve its objectives because, while it appears to be a republic and a democracy, it deprives the working class and peasants of their rights and oppresses the colonies" [5, p.296]. The bourgeois revolution built a more advanced society than feudal society, but class oppression was not abolished. It only changed from this form to another. In the end, the working class still had to suffer misery and injustice. Due to its inadequate nature, the bourgeois revolution could not bring independence and happiness to the Vietnamese.

When the desire for the path to national liberation became more urgent, Nguyen Ai Quoc found V. I. Lenin's "Preliminary Draft Theses on the National and the Colonial Questions" in July 1920. Since its title was related to the colonial issue, it immediately caught his attention. Lenin's Theses, which addressed imminent problems like equal rights for nations, Communist International's support for the colonial revolution, and the link between the proletarian and colonial revolutions, had shaped his clear political viewpoint. It was "a port in a storm", making him affirm that: "O afflicted compatriots! This is what we need. This is the way to our liberation." After ten years of unceasing 
revolutionary activities, he finally found a way to save the country: The proletarian revolution. His clear perception led to resolute action. Therefore, at the 18th Congress of the French Socialist Party, he, together with other comrades, voted to establish the Communist Party-French Section of the Communist International. It was considered a turning point in his journey to seek a path to free the country. From a patriot, he became Vietnam's first communist and a co-founder of the French working class' revolutionary political party. From here, the Vietnamese revolution entered the orbit of the proletarian revolution under his guidance.

There were several well-known names in Paris in this period, including Phan Chu Trinh, Phan Van Truong, Nguyen The Truyen, and Nguyen An Ninh. However, Nguyen Ai Quoc was the only one who caught the light of the times. His success put an end to the Vietnamese nation's half-century-long journey for national salvation and marked the beginning of the national liberation movement globally.

Fourthly, Ho Chi Minh persistently struggled with the Communist parties of Western Europe and Communist International on the colonial issue.

Nguyen Ai Quoc, aware of his country's slavery condition, was constantly concerned about the destiny of the colonial peoples. To express his dissatisfaction with the unrighteous colonial system, he said: "The territory of the colony of England is 252 times greater than the area of England. France's colonial region is 19 times bigger than its territory" [4, p.299]. It meant that many peoples became slaves in their homeland. Thus, the liberation of the colonial peoples was a matter of the nature of the times. In meetings, he continuously talked about the distressing times in the colonies and criticized the indifference and ignorance of the proletariat towards the colonial issue. Being the only delegate of Indochina at the 18th Congress of the French Socialist Party, he said: "On behalf of mankind, all socialist party members, both left and right, we hope all of you to help us" [4, p.35]. He also highlighted that their aid could be demonstrated via specific and practical acts rather than words or sympathy. After participating in the French Communist Party, he went to several units to clarify: "What kind of the revolution do you make if you do not criticize colonialism and support the colonial peoples?" [7, p.585]. He was so fervent that he mentioned the colonial issue and the Communist parties' responsibility in helping the colonial revolution three times in all three presentations at the Comintern's 5th Congress (1924) in the Soviet Union. He frankly declared: "As a member of the French Communist Party, I regret to admit that the French Communist Party has not given much support to the colonial countries" [4, p.300]. Besides, he stated emphatically: "If the Communist parties do not help the colonial revolution, the struggle in their nations becomes meaningless."

For an ordinary person, having an opinion and being ready to defend his opinion is bravery. Therefore, for a young man from a colonial country who just entered politics, criticizing his organization and superiors on large forums was a "shocking" action. Nguyen Ai Quoc showed the qualities of a true communist by openly acknowledging the organization's weaknesses, performing serious questioning, criticizing, and self-criticizing to expose the truth and implement the truth.

Fifthly, Ho Chi Minh was incredibly creative in establishing the Communist Party of Vietnam and the Party's international relations.

The revolutionary party played an indispensable role in the revolutionary movement. Therefore, the establishment of the Communist Party in Vietnam was an objective requirement. However, the question was: "Is it possible to "apply" Lenin's views on establishing communist parties in Western European countries to Vietnam?"

Nguyen Ai Quoc's stuff was shown when he introduced a particular rule: "The patriotic movement is the third factor contributing to the birth of the Communist Party of Vietnam. It is crucial to apply Marxism-Leninism to the workers' movement and the patriotic movement." After returning to Guangzhou in 1925, he was not impatient to found the Party. Instead, he decided to establish an organization, considered the "first truly Marxist organization in Indochina" and "the beginning of Vietnamese Communism", namely the Vietnamese Revolutionary Youth League, to promote the vital factors in establishing the Party. In the early 1930s, three communist organizations were born in Vietnam. As an envoy of the Communist International, he actively convened a conference to unite them in Hong Kong - China. He made some decisions that were "not under the Communist International's remote direction" [9, p.131] but were thoroughly consistent with revolutionary conditions in Vietnam. To begin with, he formed the Communist Party of Vietnam rather than the Indochinese Communist Party. Next, he consolidated communist organizations, not "purifying" them as required by Communist International. Finally, he affirmed the extensive social base of the Party, not limiting it to the working class. His correct views have been proven by history.

For a communist party established in an isolated Eastern country like Vietnam, it is challenging to build a foreign policy and handle international relations. However, Nguyen Ai Quoc was ready to accept this onerous duty. Because he supposed that the Vietnamese revolution was a part of the world revolution, he built a strategy of international solidarity to break the loneliness of the Vietnamese revolution. Besides the guidelines, he also created a link between the Communist Party of Vietnam, the French Communist Party, and the Communist International. As a result, the Executive Committee of Communist International recognized the Indochinese Communist Party as an affiliated independent unit in April 1931. The international relations he formed enhanced the power of the Communist Party of Vietnam.

Sixthly, Ho Chi Minh did not copy but applied and developed Marxism-Leninism creatively. 
Finding the truth is tough, but practicing it is more complicated. Understanding the "open" character and practical principles of Marxism-Leninism, Nguyen Ai Quoc understood that turning Marxism-Leninism into a "bible" and a cliché formula meant removing it from life. Therefore, loyalty had to be associated with creativity and critical thinking. With that view, in 1924, he wrote: "Karl Marx builds his doctrine on a certain philosophy of history. But what history? It is European History. What is Europe? It's not the whole of humanity" [4, p.509-510]. Therefore, it was obligatory to supplement and strengthen Marxism with the data of Eastern history.

It is true that "practices that are consistent with values". The national liberation program drafted by Nguyen Ai Quoc included many points contrary to the guidelines of the Third International. While Comintern upheld the class struggle, he affirmed that defeating the imperialists was a priority since the class conflict in Vietnam was not as severe as it was in the West.

The Communist International supposed that the revolutionary forces were workers, peasants, and soldiers. However, Ho Chi Minh said: "the revolutionary nation has not yet divided into classes, that is, scholars, peasants, workers, and merchants agree to oppose the great power" [5, p.278]. The Comintern believed that the success of the national revolution could release to the colonial peoples. In contrast, Nguyen Ai Quoc asserted that the colonial revolution could succeed first, helping the national revolution advance. It is necessary to put the "bold paradoxes" that he had stated in the context of Third International falling into the "leftist" trend to see his bravery partly. Although he foresaw the consequences of "contradictory" views, the survival of the Vietnamese revolution and the genuine communist's responsibility to seek the truth prompted him to put forth new views boldly. Reality indicated that his imagination not only allowed Marxism-Leninism to adapt to a new environment but also helped the Vietnamese revolution overcome dogmatism and "leftist", which were extremely hazardous. The new things constantly arise in isolation, so the brave will find creativity.

Lastly, Ho Chi Minh overcame many difficulties and challenges to actively carry out revolutionary activities and fulfill his ideals.

Participating in the revolutionary path in "a foreign place", Nguyen Ai Quoc had to face many difficulties. To begin with, he had to make a living. Leaving his homeland with his bare hands, he had to work hard and practiced "proletarianization". Due to having "strived" to do heavy jobs such as kitchen assistant, waiter, shoveling snow, burning furnaces, washing pictures, painting statues, and selling newspapers, he deeply sympathized with the working masses. However, his job was more and more difficult due to the obstruction of the local government. He should have had the opportunity to earn much money and live a comfortable and wealthy life, but he skipped it to devote his life to the cause of human liberation. Rejecting the wealth and accepting and overcoming material hardship for achieving objectives were known as the stuff.

Nguyen Ai Quoc had to practice hard with high determination, overcome all difficulties and hardships to reach a certain position in the political life of France and the world. Due to not being able to pursue an academic career at school, he said: "I have no idea about political issues... I don't know about the party, the trade unions, and even the difference between socialism and communism... I also know very little about the October revolution and Vladimir Lenin. I haven't read any of his works" [7, p.583]. To make up for those shortfalls, he was deeply immersed in life and used every opportunity and time to persevere in self-education. The relevant knowledge "distilled" from practice made him be a professional political activist, thinker, and outstanding journalist of the world communist movement.

As the man who declared war against the colonial regime, Nguyen Ai Quoc had to face the bribes and threats of the authorities and the attack of hostile forces. Before his exceptional temperament, secret agent Arnous (Louis Arnous) foreshadowed: "This slim and vibrant young man could be the one to end our dominion in Indochina" [8, p.80]. Minister of Colonies, Albert Saro, summoned Nguyen Ai Quoc to intimidate and bribe him. Nevertheless, he replied: "The important things are that my countrymen are free, and my nation is independent" [1, p.134]. As a result, his every move was followed by secret agents because he was considered a dangerous figure of the colonial regime. He was not afraid but frankly wrote an open letter to Albert Saro to attack the fact that he had "given" each Annam a devoted servant (!). When being slandered by Outrey - a colonial-minded official, he immediately responded with sharp arguments and words: "If information is provided without "evidence, would you tell me, which of us, who is the slanderer, who is the slandered, and who deserves the title of asshole?... I must tell you, without hatred and fear, but frankly and face to face, that you have lied. You are a liar" [4, p.23]. Standing up to the colonial government and still preserving life is not easy for everyone.

Sometimes, he had to suffer the misunderstanding of the organization and the assassination plot of the imperial forces. His creative views were not accepted by the Comintern due to the lack of conditions to master the situation in Indochina. Under the direction of the Communist International, the 1st Central Conference (October 1930) of the Indochinese Communist Party decided to "destroy the Party's old policies and regulations" [2, p.112] drafted by Nguyen Ai Quoc. They argued that these documents had made the dangerous mistake of nationalism. At that time, the imperialist enemies relentlessly pursued him. In 1929, a Court in Vinh (Nghe An Province) granted him the death sentence in absentia. On June 6, 1931, he was arrested in Hong Kong and detained in Victoria Prison. However, his determination, energy, and intelligence had made a good impression on lawyer Francis Henry Loseby who tried everything to force the Hong Kong government to release him. Along with "contradictory" views, the fact that a British lawyer helped Nguyen 
Ai Quoc escape the imperial prison created the suspicion of the Communist International. The situation was so tense that they set up a committee to investigate his case. The examination committee concluded that although evidence about his disloyalty hadn't been found, he had made some serious mistakes in his clandestine operations [see 1, p.6]. Between 1934 and 1938, Nguyen Ai Quoc was frequently sent to study due to the lack of "basic training" and "poor theoretical level." It meant that he could not work in the Party for a long time. This "sad" situation ended after he had sent a letter asking his organization "not to let me rest too long and like living on the side and outside of the Party" [6, p.117]. On September 29, 1938, not being a staff of the Institute for the Study of Ethnic and Colonial Affairs, he quickly went to China to find a way back to his country. The most important thing was that although his comrades misunderstood him, he never wavered his aim. He was absolutely loyal to the organization and patiently waited for another chance to realize the idea that had been cherished in 30 arduous years.

To sum up, it is challenging for us to reach success. The journey of national liberation is even more difficult. Ho Chi Minh demonstrated an "extraordinary" will, outstanding intelligence, remarkable vision, and unique perseverance to become a person who changed the nation's destiny and contributed to human history in the twentieth century. Unimaginable obstacles have molded the cultural hero's prodigious skill and spirit. A legendary journey has created a fabled life. His journey is known as a beautiful historic milestone of our country, giving the Vietnamese generations valuable lessons and inspiring ambitions.

\section{References}

1. Ba Ngoc. Investigation Committee of Nguyen Ai Quoc's case at the Communist International // Past and Present Journal. 2013. No. 438.

2. Communist Party of Vietnam. Complete Collection of Party Documents, vol.2. Hanoi: National Political Publishing House, 2002.

3. Ho Chi Minh - Biographical Chronicle, vol.1. Hanoi: National Political Publishing House, 2016.

4. Ho Chi Minh. Complete Volume, vol.1. Hanoi: National Political Publishing House, 2011.

5. Ho Chi Minh. Complete Volume, vol.2. Hanoi: National Political Publishing House, 2011.

6. Ho Chi Minh. Complete Volume, vol.3. Hanoi: National Political Publishing House, 2011.

7. Ho Chi Minh. Complete Volume, vol.15. Hanoi: National Political Publishing House, 2011.

8. Hong Ha. Uncle Ho's youth. Hanoi: Youth Publishing House, 1999.

9. Mach Quang Thang. Ho Chi Minh, a man of life. Hanoi: National Political Publishing House, 2010.

10. President Ho Chi Minh - A hero of national liberation - great culturalist. Hanoi: Social Science Publisher, 1990.

11. Tran Dan Tien. Stories of President Ho's Life in (Revolutionary) Activities. Hanoi: Truth National Political Publishing House, 2015.

12. Vladimir Lenin. Complete Volume, vol.26. M:. Progressive Publishing House, 1980. 